\title{
FACTORS INFLUENCING THE ADOPTION OF INFORMATION \\ COMMUNICATION TECHNOLOGY (ICT): IN SELECTED, RATED, HOTELS IN ADDIS ABABA, ETHIOPIA
}

\author{
Menen Agegnehu', Kenenisa Lemi ${ }^{2} \&$ Firew Mulatu ${ }^{3}$ \\ ${ }^{1}$ Rearch Scholar, Jimma University, Ethiopia \\ ${ }^{2}$ Assistant Professor of Commerce and Management, Jimma University, Ethiopia \\ ${ }^{3}$ Lecturer Department of Management, Jimma University, Ethiopia \\ menish.agn@gmail.com, kenenisalemi@gmail.com
}

\section{Original Scientific Paper doi:10.5937/jouproman7-22841}

\begin{abstract}
Information communication technology has important impact in our day to day activities. ICT to be recognized it has to be diffused in the community to see and get its effects. Adoption of ICT has become a key enabler of technology readiness in many countries. The purpose of this study is to investigate factors influencing adoption of ICT in star rated hotels with focus on 3,4 and 5 star hotels in Addis Ababa. Thus, the study investigates how organizational, manager's ICT knowledge, technology innovation and environmental factors influencing ICT adoption in management of hotels. The study used both primary and secondary data. Questionnaire was adopted from a similar study and passed reliability test. Descriptive, correlation and multiple linear regression was used to analyze the data. Finding revealed that Organizational related factors, Manger's ICT knowledge, Technology innovation factors and Environmental factors were influenced the adoption of ICT in the hotel management. Technology innovation determines ICT adoption in hotel management to a great extent followed by Environmental factors, ICT knowledge of Owner's/Managers and Organizational factor. It is recommended that the owners/mangers of the hotel needs to understand the benefit of adopting the ICT and make the technology easier to their customers and employees for sustainable ICT adoption.
\end{abstract}

Key words: Adoption, Ethiopia, Information communication technology, Hotel

\section{BACKGROUND OF THE STUDY}

Information and Communication Technologies (ICTs) play a big and catalyst role in today's business environment. The rapid growing effect of globalization and advancement in ICT has brought about remarkable improvements and great opportunities for developing countries to participate expressively in the global digital economy. ICT originates from the combination of three interrelated words: Information, Communication, and Technology. Information refers to the summarization of data. As data is raw facts and figures, it needs to be summarized, processed, and presented in different formats like lists, spreadsheets, images or audio and video ( O'Brien, 2011).

According to the global innovation index (2017), the far advanced and developed countries such as USA, Japan and Singapore are an example for the countries with advanced technological environment and infrastructure. Similarly, in Africa, the technology advanced countries are South Africa, Egypt and Nigeria. Almost in all countries, technology readiness became a key enabler (KSF) in business sectors. 
According to Alice (2017), most of the organizations including banks, insurance companies and service companies have adopted ICT and consider it as a KSF, because it has turned out to be the motivating force that is significant in the production and delivery of goods and services in those industries. However, from user's point of view the tools should be evaluated for appropriateness, effectiveness, and usability.

In Ethiopia, the total contribution of Travel and Tourism to GDP was ETB 78 million (5.7\% of GDP) and there were $1,236,000$ jobs in 2016 (5.1\% of total employment) and expected to be raised by $7.1 \%$ in 2017(WTTC, 2017). Moreover, one of the important strategies of Ministry of Culture and Tourism (MOCT) is to enhance the ICT infrastructure. Nevertheless, this steady growth in the sector shows that the industry is contributing a lot for the Growth and Development Plan (GDP) of the Country. In most developed countries the ICT adoption in their daily business is one of the high-level contributor for their GDP ( AlGhamdi, 2012).

In the hotel industry, the hotels are classified in star rating system that includes 5-star the higher luxury, 4-star Hotels, 3-star Hotels, 2star Hotels and 1-star Hotels. The United Nations World Tourism Organization (UNWTO) team determines whether the hotels receive from one to five stars, based on the facilities and the service they are offering. The various ICTs that have been adopted in the hospitality industry in Ethiopia include, using telephone lines, faxes, and cell-phones for their communication purposes both to staff and clients. Internet services including email have been adopted by hotels like 3-star and above hotels (Demeke, Small and Micro Business Enterprises (SMBEs) in Addis
Ababa, Ethiopia: Development and Poverty Reduction through Information and Communication Technologies (ICTs), with particular reference to the hotel industry and associated businesses, 2014).

According to the information published by the Ministry of Culture and Tourism (MOCT,2016), there were twenty-eight (28) registered three stars, fifteen (14) four stars and seven (7) registered five star hotels in Addis Ababa (A.A).As stated by MOCT (2016), the minimum requirement of ICT adoption for 3 star and above hotels includes: uses of email, internet, Wi-Fi public, Wi-Fi un public areas and wireless in all rooms and dedicated data line provided in all rooms. This study investigates Factors Influencing the Adoption of Information Communications Technology (ICT) in Hotel Management in 3starsuch as Hilton Addis, 4 star such as Intercontinental and 5 star such as Sheraton Addis hotels in A.A.

\section{STATEMENT OF THE PROBLEM}

Information communication technologies have a major role in enabling the conditions for industries to generate economic growth and development by reducing poverty. Thus, supporting this role, researchers accepted the role of the ICT as a facilitator for the growth and development (Sachs 2006\&Heeks 2012).

With the quick advancement of ICT globally, adoption of ICT in Ethiopian companies has become increasingly important especially for the tourism industry. Moreover, Ethiopia has become one of the African countries to be recognized by its eight heritage site registered on United Nations Educational, Scientific and Cultural Organization (UNESCOs) in Africa. 
Besides, as stated on the Ethiopian Herald (2017), Addis Ababa is a gateway to all international inbound, outbound and transit tourist passengers. Thus, Ethiopia has a great potential to grow as tourist destination. Ina similar manner, according to the report by Siboe (2017), the increasing number of hotels and tourism services contributed to the GDP and employment opportunities for many citizens. Despite vital role played by ICT in service, the adoption of ICT in Ethiopian hospitality and tourism industry has been slow (Kidane-Mariam, 2015).

The lack of diffusion of ICT in Addis Ababa leads to no research attention and this study attempts to fill the gap. According to the theoretical literatures there are factors that influence the ICT adoption in hotel namely: organizational, manager's ICT knowledge, technological innovation, and environmental factors which are not yet properly addressed through research ( Ifeanyi, Ubani, \& Asiegbu, 2014). This study tries to find if those factors are really the factors that influence the ICT adoption in star rated hotels in Addis Ababa.

In Ethiopia, as far as the researcher knowledge is concerned, there are only few studies conducted regarding adoption of ICT in SMEs and other sectors. Besides, those studies were not on star rated hotels. For instance, some of the studies were emphasized on Banking industry (Meseret, 2010, Ayana, 2014, Bisrat, 2015, Yalew, 2015), Hotel Industry in SME (Demeke, 2014), Transport industry (Sintayehu, 2014), Textile \& Leather industry (Kumlachew, 2015). Moreover, the methodology of study conducted by Demeke (2014) was descriptive and it doesn't show the relation between the factors that influence the ICT adoption. Thus, this research tries to fill this gap by using both descriptive and inferential statistics.

Therefore, since there are gaps on the literature and knowledge in general and also at micro level in the ICT adoption, the researcher believes that this study is very timely in order to fill these identified knowledge, literature, and local specific factors gap. Besides, it is very important to know whether these identified factors are actually influencing the ICT adoption as pre specified goal.

\section{Research Questions}

What is the current level of ICT Adoption practice in hotel management (A.A)?

What is the influence of organization factor on adoption of ICT in hotel management in A.A?

What is the influence of the manger's ICT knowledge on the adoption of ICT in hotel management in A.A?

What is the influence of technology innovation factor on adoption of ICT in hotel management in A.A?

What is the influence of environmental factor on ICT adoption of hotel management in A.A, Ethiopia?

\section{OBJECTIVES OF THE RESEARCH}

\section{General Objective}

The purpose of this study is to investigate factors influencing the adoption of ICT in management of hotels in A.A focusing on three, four and five-star hotels in Addis Ababa, Ethiopia. 


\section{Specific Objectives}

To investigate the current level of ICT adoption practice in hotel management in A.A.

$\checkmark$ To examine the influence of the organizational factor on adoption of ICT in hotel management in A.A.

$\checkmark$ To identify the influence of the manger ICT knowledge on the adoption of ICT in hotel management in A.A.

$\checkmark$ To explore the influence of technology innovation factors on adoption of ICT in hotel management in A.A.

$\checkmark$ To determine the influence of environmental factors on adoption of ICT in hotel management in A.A.

\section{REVIEW OF LITERATURE}

\section{Empirical Literatures}

Khemthong (2007) has conducted a study on adoption of internet and web technology in hotel marketing: a case of Thailand and Australia hotles. The object of the research was to investigate the different factors affecting the adoption of Internet and Web based marketing activities (IWMA) in Thai and Australian hotels. This study includes four independent variables: organizational (hotel size, hotel type, top management support, organization readiness, owner/manager attitude), owner/manager's ICT knowledge (utilization of computer, internal and external communication), Technology innovation (perceived benefits, compatibility and ease of use) and environmental (Customer power, level of government support, level of technology support and competition). The study used a mixed approach.
The finding revealed that: organizational (hotel size, top management support, managers), manager's ICT knowledge, technology innovation (compatibility) and environmental (customer power, competition and level of technology support) factors have a positive significant effect on adoption. Furthermore, the study found on Thailand hotels: organizational (hotel size, organizational readiness), technology innovation (perceived benefit, compatibility) and environmental (customer power and level of government support) factors has a positive significant effect on ICT adoption. Mengistu (2016) examined the factors affecting ICT adoption towards the competitiveness SMEs in the case of UPAREZ. The study used questioner and document observation as an instrument for data collection, and mixed research approached for data analysis. The researcher found that top management/owner support, centralized business management, owner's/ manager's ICT awareness, improved market performance, ease of use, speed up business processes, size (number of sales outlet or customer), increased efficiency and effectiveness, government's regulation and law, quality of IS systems and capabilities has a positive influence towards adoption. Furthermore, the barriers to adopt the ICT were of inadequate ICT strategy, lack of government incentive, lack of perceived economic or other benefits to the unit, reluctance of personnel to use ICT, lack of training\& consulting, new versions of existing software introduced too often (support fee) and expensive hardware/software. 
Hashim (2015) examined the extent of (ICT) skills, use, and adoption among owners of SMEs in Malaysia. The study used three independent variables that are: ICT skills, ICT use and innovation characteristics. The researcher identified the innovation characteristics and adopter categories among the owners; and established the relationship among them. The study used the diffusion of innovation theory. The research findings revealed that the ICT skills, ICT use, and innovation characteristic are significantly correlated to their adoption category. The researcher concluded that lower ICT skills hinders SME to use ICT and difficult to adopt. Otieno ( 2016) identified the deteminats of ICT adoption among hotles in Kenya, a mulitple case study. The key independent factors in the study are organization needs and perceived benefits,organizational capacity, technology characteristics, market characteristics and organization characteristics. The study revealed that the five mentioned factors above have a positive influence towards ICT adoption. In Ethiopia, as far as the researcher knowledge is concerned, there are only few studies conducted regarding adoption of ICT in SMEs and other sectors. Besides, those studies were not on star rated hotels. For instance, some of the studies were emphasized on Banking industry (Meseret, 2010, Ayana, 2014, Bisrat, 2015, Yalew, 2015), Hotel Industry in SME (Demeke, 2014), Transport industry (Sintayehu, 2014), Textile \& Leather industry (Kumlachew, 2015). Moreover, the methodology of study conducted by Demeke (2014) was descriptive and it doesn't show the relation between the factors that influence the ICT adoption. Therefore, since there are gaps on the literature and knowledge in general and also at micro level in the ICT adoption, the researcher believes that this study is very timely in order to fill these identified knowledge, literature, and local specific factors gap. Besides, it is very important to know whether these identified factors are actually influencing the ICT adoption as pre specified goal

\section{RESEARCH \\ DESIGN\&METHODOLOGY}

\section{Research Design}

This research problem has been studied using explanatory and descriptive research designs. Both descriptive and inferential statistics were used and analyzed the data using one-way ANOVA, Univariate analysis of variance, Pearson correlation and multiple regression analysis. This study used mixed approach. The study focused on getting quantitative data from the targeted respondents using interview questionnaires (schedules) and by referring documents (both primary and secondary sources) and for qualitative data by open- ended questions and interviews.

\section{Source \& Type of Data}

A census study has been conducted on the entire targeted population of three, four and five-star hotels in Addis Ababa. The study targeted only hotel general managers or hotel representatives. Moreover, hotel customers are not under the scope of this study as the hotels have rule not to have any interaction with their customers. 
The sources of data in this study are both primary and secondary data. The researcher used interview questionnaire and interview the front desk and ICT mangers to triangulate the data.

\section{Target Population}

According to the Ministry of Culture and Tourism, there are 28 three star and 14 four-star and 7 five star hotels in Addis Ababa and all of them operating within CBD.

\section{Data Collection Methods and Procedures}

Support letter was obtained from Jimma University to get acceptance of data collection by different stakeholders. The instrument in this study was interview administered questionnaire and key informant interview. The questionnaire was prepared to allow the respondents to give response in a standard manner which can have unbiased approach and stick with the objective.

To gather relevant data a questionnaire was prepared and administrated by the researcher and filled by the respondents. After consent that was given by $\mathrm{ABH}$ to collect data, the researcher has coordinated data collection process. The researcher has engaged two research assistants who assisted in data collection. The research assistants were trained to clearly understand the research instruments, purpose of the study and ethics of research. The researcher and research assistants were administered the questionnaires to the respondents face to face.

\section{MODEL SPECIFICATION}

The following model was developed based on the variables of the study

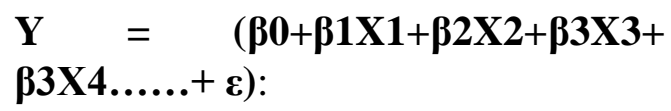

Where

$\mathbf{Y}$ is dependent variable which is affected by independent variables.

$\boldsymbol{\beta 0}$ is an intercept, where the regression line crosses the y-axis

$\boldsymbol{\beta 1 . . . . . ~} \boldsymbol{\beta n}$ is the partial slope for $\mathrm{X} 1 \ldots . . . \mathrm{Xn}$ indicated the changes in $\mathbf{Y}$ for one unit changes in $\mathrm{X} 1 \ldots \ldots \mathrm{Xn}$ other independent variables constant

$\boldsymbol{\varepsilon}$-Error terms

The model for this study:

ICT Adoption= $(\beta 0+\beta 1 X 1+\beta 2 X 2+\beta 3 X 3+\beta 3 X 4 \ldots . .$. $+\varepsilon)$ :

$\mathbf{X} 1=\quad$ Organizational, $\quad \mathbf{X} 2=$ Owner's/Manager's ICT knowledge, $\mathbf{X 3}=$ Technology Innovation, $\mathbf{X} 4=$ Environmental

Therefore, the model explained below:

ICT Adoption $=\quad(12.023+$ 0.284(Organizational factor) +2.521(Manger's ICT knowledge factor) +8.146 (Technology Innovation factor) +3.713 (Environmental factor) $+\varepsilon$ 


\section{RESULTS AND DISCUSSION}

\section{Descriptive Statistics}

\section{Adoption of ICT in the targeted Hotels}

The ICT adoption level was assessed by asking respondents the presence, application and functionality of 37 different ICT hardware and software Table1:ICT Adoption in four operation domains systems in the hotels. The component of assessment parts was room division, food and beverage, general service and in-room ICT component were assessed with different proxy item questions for each. By doing so the percentage of adoption of ICT in different departments summarized and the total percent of ICT adoption was calculated.

\begin{tabular}{|l|r|r|r|r|r|}
\hline & $\mathrm{N}$ & Minimum & Maximum & Mean & $\begin{array}{c}\text { Std. Deviation } \\
(\%)\end{array}$ \\
\hline ICT Adoption in Room Division & 49 & 56 & 100 & 82.09 & 14.666 \\
\hline $\begin{array}{l}\text { ICT adoption in Food and Beverage } \\
\text { Department }\end{array}$ & 49 & 14 & 100 & 67.93 & 25.676 \\
\hline $\begin{array}{l}\text { ICT Adoption in General Service } \\
\text { Department }\end{array}$ & 49 & 17 & 100 & 63.44 & 19.231 \\
\hline $\begin{array}{l}\text { ICT Adoption in-room services } \\
\text { ICT Adoption percent in the }\end{array}$ & 49 & 38 & 100 & 66.07 & 18.750 \\
\hline Assessed Hotels & 49 & 100 & 69.88 & 16.499 \\
\hline
\end{tabular}

SOURCE: OWN SURVEY, 2017

In addition, the study requested respondents to indicate whether their organizations have adopted ICT in their management process. All respondents indicated that their firm have adopted ICT in hotel management as this is a minimum requirement they are expected from MOCT. The assessment also shows majority of hotels adopt ICT components for room sales purpose i.e. telephone and fax systems, web site and e-mail systems, guest account management system, checkin/check-out system, central reservation system, room status and housekeeping management, customer database system and statistic and report system. On the rest of the departments almost an equal level of adoption of ICT was observed i.e. $67.93 \%$ in "food and beverage" Department, 63.44\% in "General Service' 'Department and $66.07 \%$ in "in-room services". The total mean level of adoption of ICT in hotels found $69.88 \%$ among 3, 4 and 5-star level hotels in Addis Ababa.

Hotels level of adoption was not only differed by departments but also differed with their star-levels. That means higher star levels associated $\left(X^{2}=28.498\right.$, $\mathrm{p}=0.002$ ) with better level of adoption of ICT in their departments (Figure2).

\section{CORRELATION AND MULTIPLE REGRESSION ANALYSIS}

\section{Pearson Correlation Coefficients}

The four factors in this summary are Organizational, Owner's/Manager's ICT knowledge, Technology innovation and Environmental factors. The correlation coefficient of this factors are presented below. 
(JPMNT) Journal of Process Management - New Technologies, International

Vol. 7, No 4, 2019.

Table 2 Correlation coefficient of the four factors

\begin{tabular}{|l|l|l|l|l|l|l|}
\hline \multicolumn{2}{|l|}{ Factor influencing ICT adoption } & $\begin{array}{l}\text { ICT } \\
\text { Adoption }\end{array}$ & 1 & 2 & 3 & 4 \\
\hline \multirow{3}{*}{ ICT Adoption } & Pearson Correlation & 1 & & & & \\
\hline & Sig. (2-tailed) & & & & & \\
\hline Organizational & Pearson Correlation & $.843^{* *}$ & 1 & & & \\
\hline & Sig. (2-tailed) & 0.000 & & & & \\
\hline ICT knowledge & Pearson Correlation & $.806^{* *}$ & $.448^{* *}$ & 1 & & \\
\hline & Sig. (2-tailed) & 0.000 & 0.000 & & & \\
\hline Technology & Pearson Correlation & $.872^{* *}$ & $.482^{* *}$ & $.406^{* *}$ & 1 & \\
\hline & Sig. (2-tailed) & 0.000 & 0.000 & 0.000 & & \\
\hline Environmental & Pearson Correlation & $.799^{* *}$ & $.432^{* *}$ & $.494^{* *}$ & $.437^{* *}$ & 1 \\
\hline & Sig. (2-tailed) & 0.000 & 0.000 & 0.000 & 0.00 & \\
\hline
\end{tabular}

**. Correlation is significant at the 0.01 level (2-tailed).

Source: Own Survey, 2017

As shown in table (21), there are positive strong correlations between organizational, Owner's/Manager's ICT knowledge, Technology Innovation and Environmental factors towards ICT adoption. To mention on the correlation coefficients and significance level respectively: Organizational factor $(\mathrm{r}=0.843, \quad \mathrm{P}<0.01), \quad$ Owner's/Manager's ICT knowledge factor $(\mathrm{r}=0.806, \mathrm{p}<0.01)$, Technology Innovation factor $(\mathrm{r}=0.872$, $\mathrm{p}<0.01)$ and Environmental factors $(\mathrm{r}=0.799, \mathrm{p}<0.01)$ were observed. Hotels. A high correlation will determine the contribution of each independent variable to the dependent variable. There is a strong positive correlation between organizations, manager's ICT knowledge, Technology innovation, Environmental factors towards ICT adoption.

\section{Coefficient of Determination}

The multiple regression analysis was done using the four variables namely: organizational, Owner's/Manager's ICT knowledge, Technology Innovation and Environmental Factors.

Table 3 Model summary for factors influencing ICT adoption

Model Summary

\begin{tabular}{|l|r|r|r|r|}
\hline Model & \multicolumn{1}{|c|}{ R } & \multicolumn{1}{c|}{ R Square } & Adjusted R Square & \multicolumn{1}{c|}{$\begin{array}{c}\text { Std. Error of the } \\
\text { Estimate }\end{array}$} \\
\hline 1 & $.947^{\mathrm{a}}$ & .897 & .887 & 5.408 \\
\hline
\end{tabular}

a. Predictors: (Constant), Organizational, Owner's/Manager's ICT know, Tech innovation, Environmental

Source: Own Survey, 2017 
As shown in the model summary table (22), the adjusted R-square values explain the proportion of variance in the dependent variable. Hence, the independent variables (organizational, Owner's/Manager's ICT knowledge, Technology Innovation and Environmental factors) contribution to the ICT adoption is $88.7 \%$.

\section{Multiple Linear Regression Analysis}

The research further investigated a multiple regression analysis of Organizational, Owner's/Manager's ICT knowledge, Technology Innovation and Environmental factors towards ICT adoption. The result of the regression is indicated in the table as follow.

Table 4 Model fitness for factor influencing ICT Adoption

ANOVA

\begin{tabular}{|rl|r|r|r|r|r|}
\hline Model & & Sum of Squares & df & Mean Square & F & Sig. \\
\hline \multirow{4}{*}{1} & Regression & 11161.358 & 4 & 2790.339 & 95.413 & $.000^{\mathrm{b}}$ \\
& Residual & 1286.767 & 44 & 29.245 & & \\
& Total & 12448.125 & 48 & & & \\
\hline
\end{tabular}

a. Dependent Variable: Total ICT Adoption percent in different level star hotels

b. Predictors: (Constant), Organizational, Owner's/Manager's ICT know, Tech innovation, Environmental

Source: Own Survey, 2017

Table above indicated that the $\mathrm{F}$ statistics is statistically significant indicating the fact that the model used for analysis in appropriate.
The regression analysis used to indicate the effect of independent variables on the dependent variable is indicated in the following table.

Table 5 Regression coefficients of factor influencing ICT Adoption

\begin{tabular}{|c|c|c|c|c|c|c|c|}
\hline & & & Coefficients $^{\mathrm{a}}$ & & & & \\
\hline \multirow[t]{2}{*}{ Model } & \multicolumn{2}{|c|}{$\begin{array}{l}\text { Unstandardized } \\
\text { Coefficients }\end{array}$} & $\begin{array}{l}\text { Standardized } \\
\text { Coefficients }\end{array}$ & \multirow[t]{2}{*}{$\mathrm{t}$} & \multirow[t]{2}{*}{ Sig. } & \multicolumn{2}{|c|}{$\begin{array}{c}\text { Collinearity } \\
\text { Statistics }\end{array}$} \\
\hline & B & Std. Error & Beta & & & Tolerance & VIF \\
\hline (Constant) & 12.023 & 5.524 & & 2.176 & .035 & & \\
\hline Organization & .284 & .092 & .292 & 3.092 & .003 & .263 & 3.801 \\
\hline ICT knowledge & 2.521 & 1.251 & .170 & 2.015 & .050 & .332 & 3.015 \\
\hline Technology & 8.146 & 1.735 & .414 & 4.694 & .000 & .302 & 3.313 \\
\hline Environmental & 3.713 & 1.727 & .191 & 2.150 & .037 & .298 & 3.355 \\
\hline
\end{tabular}

a. Dependent Variable: Total ICT Adoption percent in different level star hotels

Source: Own Survey, 2017 
As per the SPSS generated table 24, the equation

\section{$Y=(\beta 0+\beta 1 X 1+\beta 2 X 2+\beta 3 X 3+\beta 4 X 4+\varepsilon)$} becomes:

$\mathrm{Y}=12.023+0.284 \mathrm{X} 1+2.521 \mathrm{X} 2+$

$8.146 \mathrm{X} 3+3.713 \mathrm{X} 4+\mathrm{e}$

$\mathrm{Y}=\mathrm{ICT}$ adoption,

$\mathbf{X 1}=\quad$ Organizational, $\quad \mathbf{X} 2=$ Owner's/Manager's ICT knowledge, $\mathbf{X 3}=$ Technology Innovation, $\mathbf{X} 4=$ Environmental

The regression equation above has established by taking the four factors into account (Organizational, Owner's/Manager's ICT knowledge, Technology Innovation and Environmental) constant at zero, ICT adoption in hotel management will be 12.023. The findings also presented by taking all other independent variables at zero, a percentage increase in level of organizational factors will lead to a $0.284 \%$ increase in ICT adoption in hotel management and a percentage increase in Owner's/Manger's knowledge will lead to $2.521 \%$ increase in ICT adoption. Moreover, a percentage increase in Technology innovation will lead to $8.146 \%$ increase in ICT adoption and a percentage increase in Environmental factors will lead to a $3.713 \%$ increase in ICT adoption in hotel management. This infers that Technology innovation determines ICT adoption in hotel management to a great extent followed by Environmental factors, ICT knowledge of Owner's/Managers and Organizational factor.

\section{CONCLUSION}

The current level of ICT in the hotel management was accessed and identified. From the study findings it is inferred that majority of the hotels adopt ICT components for room sales purpose (RD). This implies that hotels are not utilizing the use of ICT components effectively in different operational domains. Thus, the ICT adoption in star rated hotels is at infant stage. By comparing the three, four and five-star hotel the researcher concludes that there is a statistically significant difference ICT adoption level observed between five star hotels and four star hotels in Addis Ababa but have no significant difference in ICT adoption level between three star and four star hotels. This shows the five star hotels adopt ICT more than three and four star hotels. The four factors organizational, ICT knowledge of the owner's/managers, Technology innovation and Environment factors have a positive significant influence towards ICT adoption. However, Technology innovation determines ICT adoption in hotel management to a great extent followed by Environmental factors, ICT knowledge of Owner's/Managers and Organizational factor.

\section{BIBLIOGRAPHY}

AlGhamdi, R. A., (2012). Diffusion of the Adoption of online Retailing in Saudi Arabia. Ph.D thesis, Griffith University. Electronic Markets Journal.

Alice, M., (2017).The Effect of Information Communication Technology Strategy Implementation on Organizational Performance of Insurance sector in Kenya. Business and change management, 4(2), pp. 742- 762. 
Ayana, G. B., (2014). Factors Affecting Adoption of Electronic Banking System in Ethiopian Banking Industry. Journal of Management Information System\& E-commerce, 1(1), pp. 1-17.

Bisrat, A., (2015). Factors Affecting the Adoption of Internet Banking Services by Customers in Addis Ababa, (Unpublished MBA thesis). Addis Ababa University, Addis Ababa.

Demeke, W., (2014). Small and Micro Business Enterprises (SMBEs) in Addis Ababa, Ethiopia: Development and Poverty Reduction through Information and Communication Technologies (ICTs), with particular reference to the hotel industry and associated businesses.

Hashim, J., (2015). Information Communication Technology (ICT) Adoption Among SME Owners in Malaysia. International Journal of Business and Information, 2(2), pp. 2520-0151.

Heeks, R., (2012). Information Technology and Gross National Happiness. Communications of the ACM, 55(4), pp. 24-26.

Ifeanyi, N., Ubani, E. \&Asiegbu, B. N. O., (2014).Factors Affecting the Adoption of ICT in the Hospitality Industry in Imo State. International Journal of Computer Science Issues, 11(4), pp. 1694-0784.

Khemthong, S. \& Roberts, L. M., (2006). Adoption of Internet and Web Technology for Hotel Marketing: A Study of Hotels in Thailand. Journal of Business Systems, Governance and Ethics, 1(2), p. 47-66.

Kidane-Mariam, T., (2015). Opportunities and Challenges of Tourism Development in Addis Ababa-upper Rift Valley Corridor. Journal of Tourism \& Hospitality Ethiopia, 4(167), pp. 2167-0269.

Kumlachew, M., (2015). Technology adoption of Ethiopian manufacturing firms: The case of textile and leather sector (Addis Ababa University, Addis Ababa).

Mengistu, G. B., (2016). Information communication technology (ICT) adoption in UPAREZ Business plc.

Meseret, Y., (2010). ICT Adoption Model for Ethiopian Banking Industry, (Unpublished MSIS thesis). Addis Ababa University, Addis Ababa.1 7.
O'Brien, J. A., (2011). Introduction to Information Systems in Business Management. 6 ed. NEW YORK: Irwin.

Otieno Obonyo, G., Ouma Kambona, O. \& Omondi Okeyo, D., (2016). Determinants of ICT Adoption among Hotels in Kenya: A Multiple Case Study. International Journal of Business and Social Science, 7(1), pp. 2219-1933.

SACHS, J. D., (2006). The End of Poverty. 10 ed. New York: Penguin Books.

Siboe, S., (2017). Opportunity for Investment in Ethiopia's Hospitality Sector, s.1.: s.n.

Sintayehu, D., (2014). Success Factors for Implementation of Enterprise Resource Planning System at Ethiopian Airlines, (Unpublished MSC thesis). Addis Ababa University, Addis Ababa.

WTTC, (2017). World Travel \& Tourism Council, London: Rochelle Turne.

Yalew, N., (2015). Impact of Information \& Communication Technology on Ethiopian private banks' performance: The case of two selected Ethiopian private banks, Unpublished EMBA thesis. Addis Ababa University, Addis Ababa. 